\title{
School Library Researchers in the Digital Age: Understanding Teaching, Research and Service in the Academy
}

\author{
Jennifer L. Branch-Mueller \\ University of Alberta, Edmonton, Canada
}

\begin{abstract}
This study presents the realities of teaching, research and service for 20 school library faculty members working on six continents. Teaching, research and service expectations vary between institutions, with $19 / 20$ of the faculty members teaching four or more classes per academic year with the numbers of students taught varying from 10 to 300 . The faculty members in this study are productive, with 9/20 publishing two or more peer-reviewed media per year. Another six are publishing one peer-reviewed media per year. Service is expected and participants in this study are all involved in faculty governance as well as service to the discipline and the profession. This research provides information to potential and current school library faculty that is helpful for making career decisions, e.g., entry to the profession, career progression, research productivity, and mentorship.
\end{abstract}

Keywords: Teaching, Research, Service, Faculty, Academies, Careers

\section{INTRODUCTION}

It has been said that life in the academy can be compared to traditional automotive garages where you could get gas, a cold can of coca-cola, your tires changed, your car fixed and, perhaps, even rent a motel room. While we rarely see these garages any more in the time of self-service gas stations, tire shops, JiffyLube, and specialized repair shops, in the academy there are still "full-service" academics. These faculty members engage in research, teaching, and service and are expected to excel in all areas to be awarded tenure and promotion.

Faculty members who work in the area of school libraries are a very small subset of those working in universities around the world. They are interesting because they work in faculties, colleges, and schools of education and/or library and information studies, tend to have professional work experience, and are predominantly female. Examining a small group of researchers from around the world who work in the same area can provide a starting point for looking at workload issues in the academy.

\section{RESEARCH QUESTIONS}

What are the experiences of the school library faculty members in the 21 st century? How do they experience teaching, research and service? How many hours a week do they teach, what conferences do they attend, where do they publish, and how do they pay for it all? What supports are in place in their units, faculties and at the university level to help these faculty members be full-service academics? This research seeks to understand the experiences of school library faculty members working in university settings in terms of teaching, research, and service.

\section{REVIEW OF THE LITERATURE}

According to Bentley and Kyvik (2011), "the modern research university - with its teaching, research and service missions - stands as the pivotal institution because it produces knowledge (research), and transmits knowledge to students (teaching) and to societal stakeholders (service)" (p. 529). In the modern research university there is still the "complete scholar' engaged in coherent, integrated, and selfdirected work across the full range of teaching, research, service, and governance" (Plater, 2008, p. 36). It 
makes sense, then, that we try to understand the experiences of faculty members in the modern research university. There is no research examining the specific experiences of school library faculty members in the global context. However, we can learn from the research of others about teaching, research and service in higher education more generally.

Gottlieb and Keith (1997) present the idea of research-oriented and teaching-oriented faculty members. While this article is old, the conceptions are interesting. Those that are research oriented are more likely to be male, more likely full professors, work at large institutions (more than 10000 students), and are more likely required to do research (95\%) (Gottlieb \& Keith, 1997, p. 404). Those that are teaching oriented are more likely to be female, work at smaller institutions (less than 2500 students), and only $75 \%$ are required to do research (Gottlieb \& Keith, 1997, p. 406). Those who lean toward research are "likely to spend one-third to two-thirds more time on research than those oriented toward teaching," teach fewer undergraduate courses, and publish more articles that those who lean toward teaching (Gottlieb \& Keith, 1997, p. 409). Webber (2011) also found that "faculty who spend more time on teaching are less productive with their research" and full professors produce more refereed journal articles than associate and assistant professors (p. 35). Interestingly, Webber found that race, marital status, and gender had no significant effect on "the production of articles, books, textbooks or presentations' (p. 35). However, financial support for research and the institution type did have an effect on productivity; "respondents from doctoral-extensive institutions report 62 percent more refereed articles than those from master's and bachelor's institutions, and respondents from research-intensive institutions report 63 percent more refereed articles than those from non-doctoral institutions (Webber, 2011, pp. 38-39).

Workload of faculty members can be examined using contract or collective agreement information such as, for example, $40 \%$ teaching, $40 \%$ research and $20 \%$ service in some researchintensive universities. However, these figures may or may not represent the actual amount of time fulltime faculty spend on the different aspects of academic work. Bentley and Kyvik (2011) report on a survey of over 7000 full-time faculty in 14 countries (Argentina, Australia, Brazil, Canada, China, Finland, Germany, Hong Kong, Italy, Malaysia, Norway, UK, and USA) to report the number of hours they spend engaging in academic work including teaching, research, and service as well as administration and other academic activities during the teaching terms (roughly $2 / 3$ of the year) and during the nonteaching term. The following table is a summary of their findings.

\begin{tabular}{|l|l|l|}
\hline Activity & $\begin{array}{l}\text { Number of hours of work } \\
\text { in teaching terms }\end{array}$ & $\begin{array}{l}\text { Number of hours of work } \\
\text { in non-teaching term }\end{array}$ \\
\hline Teaching & 19.6 & 7.6 \\
\hline Research & 15.7 & 23.9 \\
\hline Administration & 7 & 6.6 \\
\hline Service & 3.2 & 3.4 \\
\hline Other & 2.9 & 3.2 \\
\hline TOTAL & $\mathbf{4 8 . 4}$ & $\mathbf{4 4 . 7}$ \\
\hline
\end{tabular}

Table 1: Mean weekly hours on academic activities from Bentley and Kyvik (2011) pp. 535-536

A study by Link, Swann, and Bozeman (2008), using data from the US National Science Foundation, found that scientists and engineers working in Doctoral/Research Universities in the US work an average of 54 hours with the teaching, research, grant writing and service hours being 16.74, 19.42, 4.58, and 13.22, respectively. Another study, by Crespo and Bertrand (2013) found that faculty members in one research-intensive university in Canada self-reported they worked an average of 57 hours per week and spent their time in the following ways: $44.1 \%$ teaching, $35.2 \%$ research, $5.8 \%$ administration, and 14.8\% service (p. 8). Bland, Center, Finstad, Risbey, and Staples (2006) found 
similar numbers in their study with faculty reporting they spent $45.4 \%$ teaching, $26.7 \%$ research, $14.8 \%$ administration, $6.9 \%$ service, and $3.0 \%$ consulting.

Jonker and Hicks (2014) examined faculty workload at ten different universities in Ontario, Canada and reported that the average number of courses taught over two terms was 3.0 with a range from 4.5 to 2.4 with assistant professors teaching more courses that full professors (p. 21-22). The researchers also found that $19 \%$ of the sampled faculty members in chemistry had "no obvious recent contribution of scholarly and research output" (p. 45). In terms of research productivity, a study by Bland et. al (2006) of 5226 full-time faculty members reported research output in the previous two years.

\begin{tabular}{|l|l|l|}
\hline \multicolumn{1}{|c|}{ Research Output } & Recent Solo (last 2 years) & Recent Joint (last two years) \\
\hline Juried Media & 2.94 & 4.38 \\
\hline Non-juried Media & 2.21 & 1.21 \\
\hline $\begin{array}{l}\text { Published Reviews of } \\
\text { Books }\end{array}$ & 1.62 & .58 \\
\hline Textbooks & 0.79 & 0.72 \\
\hline Presentations & 10.98 & 4.99 \\
\hline
\end{tabular}

Table 2: Research Productivity for Full-time Faculty from Bland et. al (2006) p. 110

More specifically in the area of Library and Information Science/Studies (LIS), a study by Shaw and Vaughan (2008) examined the lifetime publication and citation patterns of 90 LIS faculty in the US (thirty at each rank - Assistant, Associate and Full Professor) who:

Produced 2,086 papers, chapters, articles and books. The number of publications ranged from 0 (for three assistant professors and two associate professors) to 114 (for one professor). The median number of publications rose from 7 (for assistant professors) to 17.5 (associate professors) to 37 (professors). The standard deviations were fairly large, indicating considerable variability among faculty members. It is worth noting that the standard deviation rose with rank; this means that performance gaps (variabilities) increased over the years. Productive people tended to be more productive over time, and non-productive people lagged further behind. Assistant professors published their first contribution a median of 10 years before the data were collected, which hints that active contribution to scholarship often begins before completion of the $\mathrm{PhD}$. (p. 53)

Overall, the annual publication rate was 0.7 for assistant professors, 0.9 for associate professors, and 1.3 for full professors (Shaw \& Vaughan, 2008, p. 54). A study by Wilson, Boell, Kennan and Willard (2012) examined the 2,235 journal articles published between 1967 and 2008 and compared the list to 382 LIS faculty in Australia. They found that $31 \%$ of academics had not published any journal articles and another 35\% published between one and five journal articles between 1967 and 2008 (p. 63). The remaining 34\% of faculty contributed the bulk of the journal articles (Wilson et. al, 2012, p. 63). Fourteen LIS academics accounted for over one-quarter (634) of the total number of journal articles, with school library faculty members L. Anne Clyde and Ross Todd publishing 141 articles together (Wilson et. al, 2012, p. 64). Another interesting finding from Wilson et. al was that journal articles were published mostly in national journals and a large share of the articles were published in school library journals.

Faculty service "has emerged, paradoxically, as necessary for the institutional welfare and as unacknowledged in faculty work lives" (Neumann \& Terosky, 2007, p. 284). Neumann and Terosky (2007) suggest that we need to look at service from both a content perspective (the types of activities that professors carry out in their service roles) and from a context perspective (how professors make sense of their service activities as they carry these out) (pp. 284-284). In their study of recently tenured professors, Neumann and Terosky found that service increased after tenure. This service included "work for the 
discipline or profession (e.g., recruiting and mentoring into the field, editorial and peer-review, leadership of professional and disciplinary associations, tenure/promotion reviews for other universities), or outreach and public service (e.g., community service, advisory services to national or community agencies) (p. 290). Lawrence, Ott and Bell (2012) noted that "faculty who reported they and their institutions valued institutional service highly spent more time on these activities" (p. 345). They also highlight that the reality of faculty life is that "time given to research and teaching diminished time to service" (Lawrence, Ott, \& Bell, 2012, p. 345).

This literature review examines research about faculty workload (teaching, research, and service) research productivity as well as orientation toward research or teaching. Research about faculty service is also highlighted. This research explores the experiences of the school library faculty members in the $21 \mathrm{st}$ century in terms teaching, research and service expectations.

\section{METHODOLOGY}

This research used a snowball sampling technique to find school library faculty members working in universities around the world who read and write in English. Twenty participants agreed to either be interviewed or, if an interview was impossible to schedule, to provide written responses to the interview questions. The participants also provided a copy of a current curriculum vitae so that the researcher could gather educational information, work experiences, publications, and presentations.

Participants work in universities in Canada, the United States, South America, Europe, Africa, Asia and Australia. There is representation from all ranks - Lecturer, Senior Lecturer, Assistant Professor, Associate Professor, Full Professor and Emerita faculty members.

These 20 faculty members were asked about:

- teaching responsibilities

- areas of teaching expertise

- service commitments

- research interests

- publications

- conference attendance

- supports for research

- grant opportunities

- grant support

- experiences of tenure and promotion

- experiences of being a doctoral student and a school library faculty member

The responses were analyzed by looking for common themes and trends that emerge across questions and throughout the comments (Bogdan \& Biklen, 1992; Miles \& Huberman, 1998).

\section{FINDINGS}

The findings will be reported by interview question and will be divided into parts of the interview. The first part of the interview focused on basic background information of the faculty member. The second part explored teaching expectations and experiences and the third part asked about research expectations and experiences. The fourth part focused on service expectations. Numbers, where appropriate, as well as themes and direct quotes from the participants will be used to provide description.

\section{Basic Background Information about the Participants}

The participants came from eight countries and six continents (North America, South America, Europe, Africa, Asia and Australia). Eighteen of the participants were women and two were men. There is no actual data to indicate gender representation in school library faculty but experience tells me that the majority of school library faculty members are women. Sixteen of the twenty faculty members have completed a $\mathrm{PhD}$ or EdD and three are currently in a $\mathrm{PhD}$ or EdD program. Nine of the participants have a $\mathrm{PhD}$ in the area of library and/or information science/studies and fifteen have a Master of Library and/of 
Information Science/Studies (MLIS) degree. The five participants without an MLIS degree have master's degrees in education (three participants), computer science (one), and internet studies (one).

The participants in this study work in a variety of units, departments, schools, colleges and faculties. Nine faculty members work in Schools, Colleges or Faculties of Education, three work in Colleges of Communication and Information, three work in Schools of Library and/or Information Science/Studies, one works in a School of Arts, one in a Faculty of Science, one in a Faculty of Arts and Education, one in a Faculty of Humanities and Social Sciences, and one in a Faculty of Computer Science.

\section{Workload}

During the interview, participants were asked if there was a percentage expectation for research, teaching and service. Some participants said yes and indicated this, others estimated their workload, and others indicated their personal impressions. Some did not include a percentage breakdown of their work but did highlight which areas were most important at their university. In terms of research expectations, participants indicated that research was important at all of their institutions, and the percentage of time expected to be spent on research varied from $25-60 \%$ with the average being $40 \%$. Teaching was central to the work of all participants with percentage of time expected for teaching being as high as $80 \%$ and as low as $30 \%$. The average expectation for teaching was $44 \%$. Service expectations varied as well from a low of $5 \%$ to a high of $33 \%$ with the average being about $20 \%$.

Faculty members in this study took on a variety of leadership roles. Participants reported being Chair of Department (two), Department Head (three), Program Coordinator (six), Course/Program/Certificate Director/Lead (five), and Associate Dean (one). When asked how long they worked at their current university, the answers ranged from one year to 40 years with an average of 12.5 years. Ten participants also reported working at other universities before their current position. One participant worked for 20 years at another university, but the average number of years worked at a previous university for the ten participants was 7.4 years. These previous positions included tenure-track and tenured, post-doctoral, lecturer, adjunct positions.

\section{Teaching Experiences and Expectations}

Participants were asked questions about their teaching experiences including number of courses taught per year, summer teaching expectations, online and face-to-face teaching with graduate and undergraduate students. The faculty members were also asked about class sizes, number of students taught per year and doctoral student and master's student supervision.

The teaching load of school library faculty varies greatly. Some faculty members teach two classes per term for a total of four classes per calendar year while some teach up to nine classes per calendar year. Not surprisingly, universities with higher research expectations have lower teaching expectations.

\begin{tabular}{|l|l|}
\hline $\begin{array}{l}\text { Number of three hour per week classes (3 credit } \\
\text { hours) taught in two terms/sessions }\end{array}$ & $\begin{array}{l}\text { Number of Faculty members } \\
\text { with this teaching load }\end{array}$ \\
\hline Up to 4 & 1 \\
\hline 4 & 6 \\
\hline 5 & 2 \\
\hline 6 & 5 \\
\hline More than 6 & 5 \\
\hline By student rather than by class & 1 \\
\hline Total & $\mathbf{2 0}$ \\
\hline
\end{tabular}




\section{Table 3: Teaching Expectations for two terms/sessions}

In terms of teaching in a summer term/session, all faculty members indicated that there was no expectation to teach although for many (13) there were opportunities to teach. Seven faculty members said they didn't teach in summer session. Five indicated that they regularly taught in summer session extra to their assigned teaching responsibilities.

The majority of faculty members are teaching at least some of their classes online (16) with 11 teaching only online. All faculty members are teaching graduate students and nine of the twenty teach undergraduate students as well. Class size varies from 5-150+ and faculty member reported teaching from ten to 300 students during two sessions.

\begin{tabular}{|l|l|}
\hline Numbers of students taught per year & Number of faculty members \\
\hline $0-50$ & 4 \\
\hline $51-100$ & 5 \\
\hline $101-150$ & 3 \\
\hline $151-200$ & 3 \\
\hline $201-250$ & 3 \\
\hline $251-300$ & 2 \\
\hline Total & $\mathbf{2 0}$ \\
\hline
\end{tabular}

Table 4: Number of students taught per year

Faculty members also had teaching responsibilities for student supervision of doctoral dissertations and master's theses. Fourteen faculty members are currently supervising or on supervisory committees for doctoral students. Eight are currently supervising master's thesis students. Additional responsibilities are for final projects such as capstone papers, portfolios, and research papers for nonthesis master's students. This can be a huge additional burden with some faculty members reporting being responsible for more than 100 final projects.

Supervision of practicum (practice teaching, field experience, etc.) is also considered part of teaching load for faculty members. For some, they have negotiated this supervision to be a part of their teaching load (the practicum is a class), others organize placements for students, and still others do this supervision extra to assigned teaching. Some hire adjunct instructors to visit practicum sites while others have unsupervised practicum experiences.

Teaching evaluations are very important for tenure and promotion. Faculty members agreed that tenure and promotion committees look very carefully at teaching evaluations and that they are "heavily weighted." One faculty member said that the committee needs to see "improvement" over time and that one needs to "be a good teacher" to get tenure and/or promotion. Another faculty member recounted advice given; "No one has ever NOT got tenure because of bad teaching evaluations - but don't get bad evaluations." Another felt that "teaching evaluations were more important than at other places and you can't get by with bad evaluations." One faculty member wondered if teaching evaluations were more a "popularity contest" with "awards for the highest marks." Another noted that faculty members were starting to push back a bit on teaching evaluations based on new research emerging about validity and gender bias in teaching evaluations done by students.

\section{Curriculum Design, Review, and Accreditation Expectations}

Almost all faculty members reported being involved in curriculum design and review on an ongoing basis (new courses, American Association of School Librarianship reviews, accreditation, etc.). One faculty member spoke about creating online learning modules for new curriculum. There are six or seven modules for a subject and each module can take 20 hours to complete. Several of the faculty 
members are the only ones in the area of school librarianship so they are solely responsible for curriculum review and supporting adjunct instructors who teach in the program.

Faculty members also indicated that the expectations of accreditation reviews (for example, American Library Association Committee on Accreditation (COA) and Council for the Accreditation of Educator Preparation (CAEP), Malaysian Qualification Agency, Australian Library and Information Association) are also demanding on their time. COA and CAEP happen every seven years and programs will spend two years gathering and preparing documentation.

\section{Research Experiences and Expectations}

Research is an essential part of the work that faculty members do in the academy. To better understand research experiences and expectations, faculty members were asked to discuss the research expectations of their unit and of the larger university. The interviewer also asked questions about research grants, publications, conference attendance, and research with graduate students. Participants were also asked to share their current research areas and their opinions about the premier conferences in the area of school libraries.

Thirteen of the twenty faculty members work in institutions that are research-intensive. Almost all of the school library faculty members indicated that research was an expectation of their position. One participant told the interviewer that there is an "expectation to contribute to knowledge by publishing in journals within the country and outside the country in the chosen field of specialization". Another participant indicated that the key considerations for research are "sustained productivity, impact, permanence, peer-reviewed publications, and citations". Research expectations vary; some faculty members report that expectations are very clear while others describe them as "mushy". For example, one participant noted that the rule of thumb is "ten for tenure". That is, ten peer-reviewed articles before you go up for tenure. Several participants indicate that there is an expectation of two peer-reviewed publications per year at their university. Others reported that there are no specific numbers but that research leading to peer-reviewed publications is the expectation.

Many of the participants reported that applying for grants was encouraged by the university. However, many also stated that grants are difficult to secure and credit may be given for applying. Two of the faculty members indicated that grants are required for tenure and promotion. National grants are the most prestigious.

Almost all of the participants (18) reported that conference attendance is an expectation. School library faculty are encouraged to present peer-reviewed papers at national and international conferences. Several participants (four) indicated that presenting at conferences is an expectation for tenure. Some participants also mentioned that presenting at local conferences is important for connecting with the school library community. Some (ten) receive funding every year to attend conferences, some must compete for funding (two), and some receive funding support only if they are presenting a peer-reviewed paper (four). Funding support varied from about \$1000 a year to \$2500 US dollars per year. One participant indicated that attending and presenting at international conferences was so important that she took a bank loan to pay for the travel expenses.

When asked about the premier conferences to attend, participants listed a variety of national and international conferences.

\begin{tabular}{|l|l|}
\hline Conference Name & Number of times mentioned \\
\hline International Association for School Librarianship & 9 \\
\hline American Association for School Librarianship & 6 \\
\hline Association for Library and Information Science Educators & 4 \\
\hline International Federation of Library Associations and Institutions & 3 \\
\hline
\end{tabular}




\begin{tabular}{|l|l|}
\hline American Library Association & 3 \\
\hline International Society for Technology in Education & 2 \\
\hline Australian Library and Information Association & 2 \\
\hline Nigerian School Library Conference & 2 \\
\hline
\end{tabular}

Table 5: Premier Conferences for School Library Faculty

Participants also shared conferences hosted by the Young Adult Library Services Association, the Association for Supervision and Curriculum Development, and the American Educational Research Association, as well as the European Conference on Information Literacy and Information Seeking in Context.

Participants were also asked to share their current research interests. Information literacy and information behaviour were both mentioned three times. School libraries research was mentioned six times, school library history and school library trends were both mentioned twice, and school librarians, school library leadership, school librarian/principal relationship, school librarians, co-teaching in school libraries, and school library leadership were each mentioned once. Other research topics included: digital scholarship, online learning/education (three times), digital literacy, digital curation, children's media, technology adoption, and social media in libraries. School library faculty are also doing research in the areas of library services for people with autism, action research, professional development, instructional leadership, literacy (two times), diversity, collection development, knowledge organization/management, public libraries and social capital.

Examination of the participants' current curriculum vita demonstrated that 17 of the 20 have peerreviewed articles in journals in the last five years. Journals published in English included:

The Australian Library Journal

Behaviour \& Information Technology

British Journal of Education, Society \& Behavioural Science

Catholic Library World

Communications in Information Literacy

Education for Information

Evidence-based Library and Information Practice

Information Development (3)

Information Research

The Information Technologist

International Journal of Adult Vocational Education and Technology

International Journal of Cyber Ethics in Education

International Journal of Education and Information Technologies

International Journal of the Book

Internet Research

Journal of the Association for Library Service to Children

Journal of Childhood Studies

Journal of Documentation

Journal of Education for Library and Information Science

Journal of Information and Knowledge Management

Journal of Librarianship and Information Science (2)

Journal of Research on Libraries and Young Adults

Journal of Visual Literacy

Knowledge Quest (5)

Library and Information Science Research (3)

Library Quarterly (2) 
Library Review

Library Philosophy and Practice

LIBRI (2)

Malaysian Journal of Library and Information Science (3)

Mousaion: South Africa Journal of Information Studies

New Library World

Nigerian Libraries

Nigerian School Library Journal (2)

Nordic Journal of Information Literacy in Higher Education

Ohio Media Spectrum (6)

Reading and Literacy in Nigeria

The Reading Teacher (2)

Reference Librarian

Researcher

Sankofa: Journal of African Children's and Young Adult Literature (2)

School Libraries Worldwide (12)

School Library Research (9)

Scientometrics

Synergy (2)

Teacher Librarian (2+)

Topics of QQML (Qualitative and Quantitative Methods in Libraries)

Young Adult Library Services (2)

School library faculty also had research published in conference proceedings, presented papers at international, national and local conferences, and wrote book chapters and articles for professional journals. Scholarly output was impressive with a total of 108 peer reviewed articles published in the past five years. Keep in mind that two of the participants are retired, and three are in the early years of their career.

\begin{tabular}{|l|l|}
\hline Type of Scholarly Product & Number \\
\hline Peer-Reviewed Journal Article & 108 \\
\hline Peer-Reviewed Conference Paper & 53 \\
\hline Book & 18 \\
\hline Edited Book & 3 \\
\hline Book Chapter & 55 \\
\hline Professional Article & 29 \\
\hline Conference Presentation & 81 \\
\hline
\end{tabular}

Table 6: Scholarly Output

The interviewer also asked participants if they conduct research with graduate students. Nine participants indicated that they are currently doing research with graduate students or have done research with graduate students in the past. One participant stated that one reason for doing research with graduate students is because "it is very hard to learn about research in the abstract". Through mentoring and providing opportunities for observation of research, graduate students can "soak up" understandings about research. Several participants have co-authored papers with their graduate students. One faculty member noted that it is difficult to do research with graduate students "when they are also working full-time". 
When asked about the research expectations for tenure and promotion, participants shared their perceptions. About half of the school library faculty felt that two peer-reviewed publications per year was the expectation at their university (journal article, conference proceedings or book chapter). Four participants suggested that one peer-reviewed publication was the expectation. One shared that they use a point system for tenure and promotion with 50 points required for Associate Professor and 75 points required for Full Professor (five points for a book or peer-reviewed article). Several commented that they were unsure about research expectations, that it wasn't in their contract, or that expectations were "mushy" while two others said that probation is part of the process and that tenure committees look for "significant progress towards goals". Several commented that the bar had been raised in recent years making tenure and promotion more difficult.

\section{Service}

All faculty members discussed aspects of their service commitments as part of their academic responsibilities. Expectations ranged from 5\% to 33\% of workload. Some participants felt that service was very important while others noted that service was merely "lip service". Five participants indicated that the faculty/college really values service and good citizenship is essential for the academy. All participants indicated that they provide service at the unit level and 13 indicated that they provide service at the university level. Community service included serving on local, provincial and/or state school library organizations. Participants also served on national level associations such as the American Association of School Librarians, Young Adult Library Services Association, and the American Library Association. Many faculty members also indicated that they are involved in state and national conferences as presenters and organizers.

At the international level, participants are involved in the International Federation of Library Associations and Institutions (IFLA), the International Association for School Librarianship (IASL), and the International Board on Books for Young People (IBBY). Faculty members also reported that they serve on editorial boards for several different journals. For tenure and promotion, some faculty members say that only teaching and research is important while others say that it is teaching and then service.

\section{DISCUSSION}

This research explored the experiences of 20 faculty members (eighteen women and two men) working in universities on six continents. The participants in this study work in a variety of units, departments, schools, colleges and faculties with most being in the areas of education and library and information science/studies.

\section{Workload}

In terms of research and/or scholarship expectations, participants indicated that research was important at all of their institutions and the percentage of time expected to be spent on research varied from $25-60 \%$ with the average being $40 \%$. Teaching was central to the work of all participants with percentage of time expected for teaching being as high as $80 \%$ with a low of $30 \%$. The average expectation for teaching was $44 \%$. Service expectations varied as well from a low of $5 \%$ to a high of $33 \%$ with the average being about 20\%. This was similar to other research (Bentley \& Kyvik, 2012; Jonker \& Hicks, 2014; Link, Swann, \& Bozeman, 2008).

\section{Teaching}

The teaching load of school library faculty varied greatly ranging from 2 courses per academic year up to nine classes. This was similar to other findings that suggest that teaching load varies (Bentley \& Kyvik, 2012; Jonker \& Hicks, 2014; Link, Swann, \& Bozeman, 2008), however, teaching load was much higher than in the Jonker and Hicks (2014) study done in Ontario. The high teaching load suggests that research expectations may not be as high as for some faculty members and some participants did indicate that the institution was teaching oriented (Gottlieb \& Keith, 1997). No other research explored extra session teaching as part of workload but five participants indicated they regularly taught in summer session. 
The majority of faculty members are teaching online, all teach graduate students and nine also teach at the undergraduate level with class size varying from 5-150+. The number of students taught in a year varied from ten to 300 . Teaching included supervision of graduate students dissertations, theses, and final projects, and supervision of practicum (practice teaching, field experience, etc.). Almost all faculty members reported being involved in curriculum design and review on an ongoing basis (new courses, American Association of School Librarianship reviews, accreditation, etc.), and accreditation reviews also added to the workload of almost all school library faculty members. The research done by Bentley and Kyvik (2011), Link, Swann, and Bozeman (2008) and Bland et. al (2006) with faculty members selfreporting time spent on these tasks is very interesting. Further follow-up research with these participants will include asking them to record the number of hours spent per week on teaching (including supervision of students and curriculum design and review), research (including grant writing), service, and administration (including program management and adjunct instructor supervision). It is clear that teaching is a very demanding part of the life of the school library faculty.

\section{Research}

Almost all of the school library faculty members indicated that research was an expectation of their position although other types of scholarship were valued as well. Research expectations vary; some faculty members report that expectations are very clear while others describe them as "mushy". Most institutions would like faculty members to have national grants although these are difficult to secure and credit may be given for applying. Almost all of the participants (18) reported that conference attendance is an expectation and they are encouraged to present peer-reviewed papers at national and international conferences. Some (ten) receive funding every year to attend conferences, some must compete for funding (two), and some receive funding support only if they are presenting a peer-reviewed paper (four). Funding support varied from about $\$ 1000$ a year to $\$ 2500$ US dollars per year. Premier conferences included those hosted by the International Association for School Librarianship, the American Association for School Librarians, the Association for Library and Information Science Educators and IFLA.

Examination of the participants' current curriculum vita demonstrated that 17 of the 20 have contributed 108 peer-reviewed articles in journals in the last five years. The school library faculty in this study had research published in conference proceedings (53 times), presented papers at international, national and local conferences ( 81 times), wrote or edited 18 books, wrote 55 book chapters, and wrote 29 articles for professional journals. Two of the participants are retired, and three are in the early years of their career. Six faculty members in this study were very productive (with more than 3 peer reviewed media and/or books per year), three faculty members had two peer-reviewed media per year, six had an average of one per year, five others had limited or no research productivity. This compares with other research done about faculty productivity such as Bland et. al (2006) and Shaw and Vaughan (2008). Those with limited or no research productivity worked in institutions where teaching was a priority.

\section{Service}

Faculty members reported that expectations for service in their institutions ranged from $5 \%$ to $33 \%$ of workload. All participants were involved in institutional governance committees at the unit, faculty, college and/or university level. Five participants indicated that the faculty/college really values service and good citizenship is essential for the academy (Lawrence, Ott \& Bell, 2012). Like Neumann and Terosky reported (2007), participants in this study were involved in service for the discipline or profession including serving on local, provincial and/or state, national and international school library organizations, and presenting at and/or organizing conferences for these associations. Faculty members also reported that they serve on editorial boards for several different journals.

\section{IMPLICATIONS AND CONCLUSIONS}

This study contributes to research about the experiences of faculty members in the academy. It presents the realities of teaching, research and service for 20 school library faculty members working on six continents. Teaching, research and service expectations vary between institutions, and faculty 
members report teaching loads that are very different from each other. The teaching load of 19/20 of the faculty members is four or more classes per academic year and class sizes and the numbers of students taught over two session varies from 10 to 300. The faculty members in this study are productive with 9/20 publishing two or more peer-reviewed media per year. Another six are publishing one peerreviewed media per year. Service is expected and participants in this study are all involved in faculty governance as well as service to the discipline and the profession.

Further research is needed in this area. A follow-up on research productivity in a few years would be useful to see if there are changes over time and as faculty members proceed through the ranks. Gathering self-reported time data for workload would be interesting to compare to previous research in other areas. It would also be interesting to find out more about how faculty members feel about their research productivity as compared to others in their unit. It would also be useful to interview another twenty faculty members to gather more data in all areas.

This study provides information for those interested in a faculty position in the area of school libraries. Participants worked in either research-oriented (13) or teaching oriented (7) positions and research and service expectations varied based on teaching workload. Those in research-intensive institutions had higher research expectations and those faculty members had higher research productivity than those in teaching-intensive institutions. For doctoral students in the area of school libraries interested in faculty positions, there are a variety of academic positions with different teaching and research expectations. When thinking about applying for faculty positions, it is important to find out more about an institution's teaching and research expectations and to find the right fit for your career.

This research provides information to potential and current school library faculty that is helpful for making career decisions, e.g., entry to the profession, career progression, research productivity, and mentorship.

\section{REFERENCES}

Bentley, P. J., \& Kyvik, S. (2012). Academic work from a comparative perspective: A survey of faculty working time across 13 countries. Higher Education, 63, 529-547.

Bland, C. J., Center, B. A., Finstad, D. A., Risbey, K. R., \& Staples, J. (2006). The impact of appointment type on the productivity and commitment of full-time faculty in research and doctoral institutions. The Journal of Higher Education, 77(1), 89-123.

Bogdan, R. C., \& Biklen, S. K. (1992). Qualitative research for education: An introduction to theory and methods (2nd ed.). Boston, MA: Allyn and Bacon.

Crespo, M., \& Bertrand, D. (2013). Faculty workload in a research intensive university: A case study. Quebec: Le CIRANO.

Edgar, F., \& Geare, A. (2013). Factors influencing university research performance. Studies in Higher Education, 38(5), 774-792.

Gottlieb, E. E., \& Keith, B. (1997). The academic research-teaching nexus in eight advancedindustrialized countries. Higher Education, 34, 397-420.

Jonker, L., \& Hicks, M. (2014). Teaching loads and research outputs of Ontario university faculty members: Implications for productivity and differentiation. Toronto, Canada: Higher Education Quality Council of Ontario.

Lawrence, J., Ott, M., \& Bell, A. (2012). Faculty organizational commitment and citizenship. Research in Higher Education, 53, 325-352. Doi: 10.1007/s11162-011-9230-7

Link, A. N., Swann, C. A., \& Bozeman, B. (2008). A time allocation study of university faculty. Economics of Education Review, 27, 363-374.

Miles, M. B., \& Huberman, A. M. (1998). Qualitative data analysis: An expanded sourcebook (2nd ed.). Thousand Oaks, CA: Sage Publications.

Neumann, A., \& Terosky, A. L. (2007). To give and to receive: Recently tenured professors' experiences of service in major research universities. The Journal of Higher Education, 78(3), 282-310.

Plater, W. M. (2008). The twenty-first-century professoriate. Academe, 94(4), 35-40. 
Shaw, D., \& Vaughan, L. (2008). Publication and citation patterns among LIS faculty: Profiling a 'typical professor." Library \& Information Science Research, 30(1), 47-55. DOI:10.1016/j.lisr.2007.07.002

Webber, K. (2011, July-September). Factors related to faculty research productivity and implications for academic planners. Planning for Higher Education, 39(4), 32-43. Retrieved from http://www.scup.org

Wilson, C. S., Boell, S. K., Kennan, M. A., \& Willard, P. (2012). Fifty years of LIS education in Australia: Research productivity and visibility of LIS educators in higher education institutions. Journal of Education for Library and Information Science, 53(1), 49-68. Retrieved from http://www.alise.org/jelis-2 